\title{
Advokasi Perempuan Korban Kekerasan Melalui Model Clinic Legal Education
}

\author{
Aroma Elmina Martha \\ Fakultas Hukum Universitas Islam Indonesia Yogyakarta Indonesia \\ Jln. Tamansiswa No. 158 Yogyakarta Indonesia \\ aroma@uii.ac.id
}

Received: 1 September 2020; Accepted: 1 Desember 2020; Published: 15 Desember 2020

DOI: 10.20885/iustum.vol27.iss3.art7

\begin{abstract}
This paper aims to analyze the typology of women victims of violence in using access to advocacy rights and fulfillment of advocacy for women victims of violence through a clinical legal education model. Using a normative approach through tracing primary legal materials, this paper shows that first, there are at least six groups of women in understanding access to advocacy knowledge, namely: First, groups of women who do not know their right to protection; Second, groups of women who know their rights but do not know where to go to access justice; Third, groups of women who know where to go and have the right to access justice but do not have the financial means or capacity to access justice; Fourth, groups of women who learned helpness and apathy with the condition and accepted the reality of being victims; Fifth, groups of women who fear that the perpetrators will take revenge if they seek legal assistance. Sixth, groups of women who have high awareness and seek to find solutions to the violence they experience. Second, efforts to fulfill women's advocacy rights through the development of a legal education clinic model can be pursued with a Live-client clinic and Street law clinic based on a curriculum model that is not only based on law but on the sense of community justice.
\end{abstract}

Key Words: Advocacy; clinical legal education; women; violence

\section{Abstrak}

Tulisan ini bertujuan untuk menganalisis tipologi perempuan korban kekerasan dalam menggunakan akses hak advokasi dan pemenuhan advokasi perempuan korban kekerasan melalui model clinic legal education. Menggunakan pendekatan normatif melalui penelusuran bahan hukum primer, tulisan ini menunjukkan pertama, setidaknya terdapat enam kelompok perempuan dalam memahami pengetahuan akses advokasi yaitu: Pertama, kelompok perempuan yang sama sekali tidak tahu haknya untuk mendapatkan perlindungan; Kedua, kelompok perempuan mengetahui hak-haknya tetapi tidak tahu kemana harus pergi untuk mengakses keadilan; Ketiga, kelompok perempuan yang tahu harus pergi kemana dan hak mengakses keadilan tetapi tidak memiliki sarana atau kemampuan finansial untuk mengakses keadilan; Keempat, kelompok perempuan yang learned helpness dan apatis dengan kondisi lalu menerima kenyataan sebagai korban; Kelima, kelompok perempuan yang takut pelakunya akan membalas dendam jika mereka mencari bantuan hukum. Keenam, kelompok perempuan yang memiliki kesadaran tinggi dan berupaya mencari solusi atas kekerasan yang dialaminya kedua, upaya pemenuhan hak advokasi perempuan melalui pengembangan model clinic legal education dapat ditempuh dengan model Live-client clinic dan Street law clinic dengan basis model kurikulum yang tidak hanya berbasis Undang-Undang saja namun pada rasa keadilan masyarakat.

Kata-kata Kunci: Advokasi; kekerasan; perempuan; pendidikan hukum klinis 


\section{Pendahuluan}

Isu utama dalam tulisan ini dilatarbelakangi data yang menunjukkan tingginya angka kekerasan terhadap perempuan di Indonesia. Data Catatan Akhir Tahun (Catahu) Komisi Nasional (Komnas) Perempuan pada 2019 menunjukkan, dalam kurun waktu dua belas tahun, kekerasan terhadap perempuan meningkat sebanyak 792\% (hampir 800\%). Artinya, kekerasan terhadap perempuan di Indonesia meningkat hampir delapan kali lipatselama dua belas tahun. Kekerasan terhadap Anak Perempuan (KTAP) melonjak sebanyak 2.341 kasus, yang tahun sebelumnya sebanyak 1.417 kasus. Kenaikan dari tahun sebelumnya terjadi sebanyak 65\% dan paling banyak adalah kasus inses dan ditambahkan dengan kasus kekerasan seksual; 571 kasus. ${ }^{1}$ Bahkan, Badan Peradilan Agama Mahkamah Agung mencatat angka perceraian pada 2019 sebanyak 416.752 kasus, 218.979 kasus di antaranya akibat pertengkaran terus-menerus dan 1.232 kasus karena poligami. Sementara, pengasuhan anak-anak kerap jatuh ke istri. ${ }^{2}$ Hanya tiga persen dari jumlah kasus KDRT yang dilaporkan ke aparat hukum ${ }^{3}$ sehingga akses untuk mendapatkan perlindungan hukum cenderung rendah.

Penyebaran Covid-19 memberi dampak yang menyulitkan akses advokasi bagi perempuan, korban kekerasan khususnya. Berdasarkan data Pusat Pelayanan Terpadu Pemberdayaan Perempuan dan Anak (P2TP2A) dan Komnas Perempuan, kasus kekerasan terhadap perempuan telah meningkat sebesar 75\% sejak terjadinya pandemi Covid-19.4 Sebaliknya, lembaga layanan menjadi terbatas dalam mengadvokasi.Kekurangan sumber daya menjadi kendala dengan naiknya jumlah laporan kekerasan ditambah situasi pembatasan sosial dan imbauan kerja dari rumah untuk mencegah penyebaran Covid-19. Ini memang telah menyulitkan korban kekerasan dalam rumah tangga (KDRT) maupun lembaga pemberian layanan.Para korban terjebak dengan pelaku kekerasan di rumah, terisolasi dari

\footnotetext{
${ }^{1}$ https://www.komnasperempuan.go.id/read-news-siaran-pers-dan-lembar-fakta-komnas-perempuancatatan-tahunan-kekerasan-terhadap-perempuan-2020, diakses pada Agustus 2020

${ }^{2}$ Ibid

${ }^{3}$ http://www.harnas.co/2019/04/04/penuntasan-kdrt-secara-hukum-minim, diakses pada Agustus 2020 ${ }^{4}$ https:// nasional.kontan.co.id/news/selama-pandemi-corona-kekerasan-terhadap-perempuan-naik-75, diakses pada Agustus 2020
} 
orang-orang dan sumber daya yang dapat menolong mereka. Sementara itu, pandemi juga menghambat kerja lembaga layanan dalam membantu korban. ${ }^{5}$

Kantor Staf Presiden (KSP) pada 29 April 2020 meluncurkan layanan psikologi untuk sehat jiwa (SEJIWA) yang bisa diakses melalui call center 119 ext. 8. Dalam penyelenggaraannya, KSP bekerja sama dengan Kementerian Pemberdayaan Perempuan dan Perlindungan Anak (KPPPA), Kementerian Komunikasi dan Informatika (Kemkominfo), Kementerian Kesehatan (Kemenkes), Badan Nasional Penanggulangan Bencana (BNPB), dan Himpunan Psikologi Indonsia (HIMPSI). Seminggu setelah layanan SEJIWA diluncurkan, Gugus Tugas Covid-19 mengirimkan SMS massal yang berisi imbauan untuk menghubungi nomor hotline tersebut jika seseorang mengalami atau menyaksikan kasus KDRT. Akibatnya, KPPPA kewalahan akibat lonjakan pengaduan ini. ${ }^{6}$

Kondisi ini tentu saja memprihatinkan. Peran negara untuk melindungi sebetulnya telah tertuang di dalam Undang-Undang Nomor 16 Tahun 2011 tentang Bantuan Hukum (UU Bantuan Hukum). Pasal 1 ayat (1) UU Bantuan Hukum menyatakan bahwa bantuan hukum adalah jasa hukum yang diberikan oleh Pemberi Bantuan Hukum secara cuma-cuma kepada Penerima Bantuan Hukum. Penerima Bantuan Hukum adalah orang atau kelompok orang miskin yang tidak dapat memenuhi hak dasar secara layak dan mandiri yang menghadapi masalah hukum. Sedangkan dalam Pasal 27 Surat Edaran Mahkamah Agung Nomor 10 Tahun 2010 tentang Pedoman Pemberian Bantuan Hukum (SEMA Pedoman Pemberian Bantuan Hukum), dinyatakan bahwa yang berhak mendapatkan jasa dari Pos Bantuan Hukum adalah orang yang tidak mampu membayar jasa advokat terutama perempuan dan anak-anak serta penyandang disabilitas, sesuai peraturan perundang-undangan yang berlaku. Meskipun demikian, faktanya, situasi pembatasan sosial dan imbauan kerja dari rumah untuk mencegah penyebaran Covid-19 memang telah menyulitkan korban kekerasan dalam rumah tangga (KDRT) maupun lembaga pemberian layanan.

${ }^{5}$ https://magdalene.co/story/hotline-pengaduan-kdrt-banyak-laporan-sumber-daya-terbatas, diakses pada Agustus 2020 
Tulisan ini lebih jauh akan menganalisis tipologi perempuan korban kekerasan dalam menggunakan hak advokasinya berdasarkan kajian kepustakaan, sehingga akan diperoleh uraian tipologi pertimbangan akses dalam memperoleh bantuan hukum. Di sisi lain, sistem hukum di Indonesia masih berfokus pada kepastian hukum dan prosedural, sehingga berbagai penanganan kasus kekerasan perempuan dan anak menjadi kurang maksimal.Sulitnya menggali pembuktian memberi dampak menyulitkan para korban untuk menindaklanjuti kasus kekerasan ke proses pelaporan. Pada kekerasan pemerkosaan misalnya, haruslah diperkuat melalui alat bukti visum et repertum. Padahal, jika kasus tersebut telah terjadi beberapa waktu, maka tidaklah mudah untuk menentukan kapan terjadi waktu (tempus delicti) dari perbuatan pidana tersebut. Aspek pembuktian ini tentu saja menyulitkan penyidik dalam menentukan waktu terjadinya dugaan tindak pidana tersebut.

Peran kampus melalui bantuan hukum, keterlibatan sosial, dan penanganan sosial menjadi penting di sini.Peran lembaga bantuan kampus dalam penanganan klinis khusus perempuan, utamanya di dalam aspek legal clinic (hukum klinis), sangatlah membantu dalam pendampingan; hukum klinis ini dijalankan oleh mahasiswa dengan pendampingan dosen. Hukum klinis biasanya dihubungkan dengan fakultas hukum sebagai basis operasionalnya.Klinis hukum hadir dengan maksud membekali mahasiswa fakultas hukum tentang pengetahuan praktis, keahlian-keahlian, dan nilai-nilai dalam rangka mewujudkan pelayanan hukum dan keadilan yang dilaksanakan dengan metode pengajaran secara interaktif dan reflektif.7 Bertolak dari gagasan tersebut, tentunya topik ini menjadi krusial untuk dibahas dalam rangka upaya memetakan model yang tepat agar memberi hasil yang maksimal dalam pendampingan korban.

\section{Rumusan Masalah}

Tulisan ini didasarkan pada dua isu utama. Pertama, bagaimana tipologi perempuan korban kekerasan dalam menggunakan akses hak advokasi? Kedua, bagaimana pemenuhan advokasi perempuan korban kekerasan melalui model clinic legal education?

${ }^{7}$ Lihat, Sahnan Sahuri Siregar, Otong Rosadi, "Pendidikan Klinik Hukum Sebagai Instrumen Penting Dalam Pembaharuan Pendidikan Hukum Di Indonesia”,Journal Swara Justicia, Volume 3, Issue 4, Januari 2020 


\section{Tujuan Penelitian}

Berdasarkan uraian di atas, tulisan ini bertujuan untuk, pertama, menganalisis tipologi perempuan korban kekerasan dalam menggunakan akses hak advokasi dan, kedua, pemenuhan advokasi perempuan korban kekerasan melalui model clinic legal education.

\section{Metode Penelitian}

Penulis menggunakan metode penelitian deskripsi-kualitatif dalam merampungkan tulisan ini. Tulisan ini penulis telusuri dengan menggunakan teknik kajian dokumentasi berupa riset dari jurnal maupun buku yang membahas tema yang relevan dengan judul dan pertanyaan masalah dalam tulisan. Penelitian terfokus pada dua konstruksi penting, yaknitipologi hak advokasi perempuan korban kekerasan dan upaya pemenuhan advokasi hak perempuan melalui model clinic legal education.

Teknik pengumpulan data diperoleh melalui kepustakaan berupa buku, jurnal, dan informasi kasus yang berasal sumber yang berkaitan denganjustice education dan clinic legal education. Desain tulisan ini mencakup proses pengumpulan data (referensi buku), analisis dan interpretasi data, penulisan, dan kesimpulan. Pisau metodis utama yang diterapkan peneliti yakni menggunakan pendekatan yuridis normatif, yakni melakukan kajian mendalam berdasarkan penelusuran bahan hukumyang relevan dengan topik pembahasan.

\section{Hasil Penelitian dan Pembahasan}

\section{Pertimbangan Perempuan Korban Kekerasan dalam AksesAdvokasi sebagai} Upaya Perlindungan

Teori advokasi perempuan umumnya digunakan untuk menjelaskan proses pencarian bantuan di antara para penyintas. ${ }^{8}$ Model ini cenderung berfokus pada proses kognitif internal pencari bantuan individu dengan mencakup tiga tahap;

\footnotetext{
${ }^{8}$ Penyintas adalah orang yang mampu bertahan hidup. Arti lainnya dari penyintas adalah orang yang dapat bertahan terhadap kondisi yang membahayakan kelangsungan hidup
} 
pengenalan dan definisi masalah, keputusan untuk mencari bantuan, dan pemilihan penyedia bantuan. ${ }^{9}$

Tahapan pertama, pengenalan penilaian dan pendefinisian masalah, menjelaskan mengenai kondisi seorang perempuan yang terpuruk karena situasi yang dialaminya. Iaakan dipastikan keadaannya dalammembentuk keputusannya tentang apakah dan dari siapa harus mencari bantuan hukum. Tahapan kedua, pertimbangan keputusan pencarian bantuan yang dipilih akan memengaruhi perempuan mendefinisikan dan menguraikan masalah yang dialami dan memilih untuk meneruskan mencari bantuan atau tidak. Dalam tahapan ini, terbentuk proses dialektis. Dalam istilah kognitif, emosi berkaitan dengan kognisi dan tindakan yang disengaja. Misalnya, perasaan bersalah dan malu yang mungkin timbul dari keputusan untuk mencari bantuan dapat menghalangi perempuan yang mengalami penyiksaan fisik untuk benar-benar bertindak mencari bantuan hukum berdasarkan keputusannya. Tahapan ketiga, pemilihan penyedia bantuan, proses internal ini dipengaruhi oleh faktor interpersonal dan sosio-kultural seperti riwayat individu dan relasi penyintas dengan konteks ekonomi, politik, dan budaya tempat pengalaman hidupnya tertanam.

Menurut Brandstadter, penjelasan untuk tindakan yang disengaja yang berpusat pada pengaruh dalam tindakan (seperti ekspektasi individu, tujuan, dan kepercayaan) tanpa memperhitungkan pengaruh kontekstual yang lebih luas memberikan gambaran tindakan yang ahistoris dan dinamis. ${ }^{10}$ Salah satu pertanyaan yang sering ditanyakan dalam literatur kekerasan dalam rumah tangga adalah mengapa perempuan tetap bertahan dengan kekerasan yang dialaminya? Ada keyakinan bahwa efek psikologis negatif dari kekerasan membuat perempuan tetap berada dalam hubungan yang berbahaya. Situasi lain menunjukkan, bagaimanapun, ada banyak hambatan untuk membuat perempuan terjebak dalam rumah dan mengalami kekerasan, termasuk ancaman penyerang untuk membunuh perempuan dan anak-anak mereka jika mereka mencoba melarikan diri.

9 Lisa Goodman, Pratyusha Tummala-Narra, dan Sarah Weintraub, “A Theoretical Framework for Understanding Help-Seeking Processes Among Survivors of Intimate Partner Violence Belle Liang, American Journal of Community Psychology”, Vol. 36, Nos. 1/2, September 2005

${ }^{10} \mathrm{Ibid}$ 
Sebuah studi tentang perempuan yang menerima layanan advokasi yang luas dan intensif ketika mereka memutuskan untuk pergi ke tempat penampungan sementara (shelter) menunjukkan bahwa perempuan penerima layanan advokasi lebih efektif dalam mencapai tujuannya dibandingkan dengan perempuan yang tidak mendapatkan layanan advokasi. Penelitian Fischer (1992) tentang perempuan yang mendapatkan perintah perlindungan menunjukkan bahwa sebagian besar perempuan puas dengan bantuan yang mereka terima dari advokat dalam mendapatkan pesanan. Para perempuan menilai informasi dan dukungan sebagai kontributor penting untuk kepuasan mereka dengan pesanan. ${ }^{11}$ Perempuan yang menerima layanan advokasi yang luas dan intensif lebih efektif hasilnya dalam mencapai tujuannya daripada mereka yang tidak mengakses. ${ }^{12}$ Juga, perempuan yang mendapatkan perlindungan menunjukkan reaksi lebih puas dengan sarana bantuan yang mereka terima dari penasehat hukum. ${ }^{13}$

Advokasi hukum untuk para penyintas dapat berhasil jika hal tersebut menanggapi kebutuhan relasional perempuan dengan menawarkan dukungan emosional, informasi, dan kehadiran advokat secara fisik. ${ }^{14}$ Selain advokasi, dimungkinkan kombinasi lain berupa (a) krisis hotline, (b) konseling, (c) advokasi, dan (d) tempat penampungan darurat. ${ }^{15}$

Pemilihan advokasi terhadap korban kekerasan diberikan apabila dari pihak korban menginginkan kasus mereka diselesaikan melalui cara litigasi jika diproses ke pengadilan dan non-litigasi apabila memfokuskan pada konsultasi hukum. Tentu saja, kedua bentuk tersebut disesuaikan berdasarkan pertimbangan jenis kasus kekerasan dan kondisi korban. Kasus pelecehan seksual pendekatannya berbeda dengan kasus kekerasan fisik yang mengakibatkan luka. Pada kondisi korban yang memilih non-litigasi, ada beberapa kondisi dipertimbangkan. Diantaranya, aib bila diketahui orang luar, malu karena berkaitan dengan korban pelecehan seksual, dan menjaga kehormatannya.

11 Arlene N. Weisz, "Legal advocacy for domestic violence survivors: The power of an informative relationship Families in society", The Journal of Contemporary Human Services, 1999

${ }^{12}$ Cris M. Sullivan, Cheribeth Tan, Joanna Basta, Maureen Rumptz, and William S. Davidson II, “An Advocacy Intervention Program for Women with Abusive Partners: Initial Evaluation I",American Journal of Community Psychology, Vol. 20, No. 3, 1992

${ }^{13}$ Ibid.

${ }^{14}$ Arlene N. Weisz, "Legal advocacy...Loc.Cit.

${ }^{15} \mathrm{Ibid}$ 
Mereka juga khawatir ancaman balas dendam pelaku, bahkan diceraikan oleh pasangannya.

Metode advokasi ini namun terkadang memiliki kelemahan, meskipun korban mendapat bantuan hukum, namunpendampingan ternyata hanya dilakukan pada saat pelaku berada di dalam proses peradilan sajapada praktiknya, dan bertemu dengan pelaku juga pada saat proses pemeriksaan akan dilakukan. Pendampingan jarang dilakukan sebelum proses pemeriksaan akan dilakukan, padahal seharusnya pendampingan dilakukan baik pada saat di dalam proses hukum acara maupun diluar proses hukum acara. Sebaiknya, pendampingan justru berfungsi sebagai upaya untuk memberikan pemahaman hukum bagi pelaku sehingga mereka dapat memahami posisi atau kedudukan hukum, terutama pada saat akan dilakukan pembelaan. Hal ini penting dilakukan karena perbuatan yang dilakukan tersebut memiliki latar belakang perbuatan lain yang mengandung kekerasan. ${ }^{16}$ Kenyataannya, tugas pendampingan yang dilakukan oleh penasihat hukum tidak memberikan pemahaman atau menumbuhkan pemahaman hukum bagi pelaku perempuan.

\section{Analisis Tipologi Korban Perempuan dalam Mengakses Advokasi}

1. Kelompok perempuan yang sama sekali tidak tahu haknya untuk mendapatkan perlindungan

Kelompok ini biasanya merujuk pada perempuan yang memiliki keterbatasan dalam penerimaan akses informasi. Kondisi ini terjadi pada masyarakat yang masih sederhana dan terbatasnya sosialisasi atas hak yang seharusnya diterima. Mengingat Indonesia masuk ke negara kepulauan, keadaan ini sangat mungkin terjadi.

2. Kelompok perempuan yang mengetahui hak-haknya, tetapi tidak tahu kemana harus pergi untuk mengakses keadilan

Kelompok ini biasanya merujuk pada kelompok perempuan yang memiliki keterbatasan secara finansial dan rendahnya pemahaman pendidikan yang diperoleh sehingga tidak mengetahui apa yang seharusnya dilakukan untuk mengakses keadilan.

\footnotetext{
${ }^{16}$ Lihat, Rd.Dewi Asri Yustiaet.al, "Mendobrak kelemahan litigasi konvensional melalui model advokasi mandiri dalam rangka pembaharuan proses peradilan", Jurnal Litigasi, 2015
} 
3. Kelompok perempuan yang tahu harus pergi kemana dan hak mengakses keadilan, tetapi tidak memiliki sarana atau kemampuan finansial untuk mengakses keadilan ${ }^{17}$

Kelompok ini biasanya terdiri dari perempuan yang tidak memiliki kemampuan ekonomi secara mandiri. Asumsi membayar mahal penasehat hukum membuat perempuan memilih untuk bertahan.

4. Kelompok perempuan yang learned helpness dan apatis dengan kondisi, lalu menerima kenyataan sebagai korban

Kekerasan suami terhadap istri pada umumnya memiliki akibat yang berkepanjangan dan sering terjadi secara berulang-ulang karena istri berusaha memendam perasaan untuk mempertahankan keutuhan rumah tangga. Pada umumnya, istri tidak suka dengan status janda cerai karena memiliki dampak sosial yang tidak menyenangkan. Karenanya, lebih banyak yang tetap bertahan dalam ikatan perkawinan, walaupun hidup dalam kekerasan. Adanya pergolakan batin antara penderitaan dengan keinginan untuk mempertahankan rumah tangga menyebabkan timbulnya perasaan rendah diri dan tidak percaya diri, selalu menyalahkan diri sendiri, mengalami gangguan fertilitas (kesuburan), seta gangguan siklus haid karena jiwanya tertekan. ${ }^{18}$

5. Kelompok perempuan yang takut pelakunya akan membalas dendam jika mereka mencari bantuan hukum ${ }^{19}$

Perempuan seringdihadapkan pada dilema apabila diteruskan ke proses hukum akan menimbulkan masalah baru atau tidak. Di sisi lain, respon ketidaksetujuan pihak keluarga besar dengan cara mengintimidasi bahkan justru berbalik memproses pidana menjadikan perempuan berpikir ulang untuk melanjutkan ke proses advokasi.

6. Kelompok perempuan yang memiliki kesadaran tinggi dan berupaya mencari solusi atas kekerasan yang dialaminya

\footnotetext{
${ }^{17}$ Kevwe Omoragbon, "Interface of Law and Medicine in Clinical Legal Education: Success story of the Women's Law Clinic in improving the health of women and ensuring women's access to Justice in Nigeria" Paper presented at the Seventh International Journal of Clinical Legal Education held at Murdoch University, Perth, Western Australia, July 9-10, 2009

${ }^{18}$ M. Asasul Muttaqin, et.al., "Bimbingan Konseling bagi Perempuan Korban KDRT"

${ }^{19}$ Arlene N. Weisz, "Legal advocacy...Loc.Cit.
} 
Tipe keenam ini yang akan menjadi pokok pembahasan dalam pendidikan hukum klinis. Kelompok ini menyadari perlunya peran konsultasi hukum sebagai upaya jalan keluar atas permasalahan yang dihadapi. Jika mengacu pada teori advokasi di atas, tahapan pengenalan dan definisi masalah didasarkan pada pengalaman yang berbeda-beda. Ini tergantung pada kondisi apa yang dialami perempuan. Pada kelompok pertama, biasanya berada dalam wilayah yang belum terjangkau dengan ketersediaan informasi bantuan hukum. Begitu pula pada kelompok kedua, perempuan yang mengetahui haknya namun tidak tahu ke mana harus pergi dikarenakan akses untuk mendapat informasi bantuan hukum yang kurang memadai.

Ketiadaan akses yang setara pada keadilan yang dialami perempuan juga terkait dengan persoalan penegakkan prinsip equality before the law (persamaan di muka hukum) dalam praktik hukum. Secara ideal, prinsip tersebut baru dapat berlaku efektif bila setiap orang memiliki akses yang sama kepada sumber daya dan keadilan. Pentingnya prinsip persamaan (egaliter) di muka hukum diterapkan dalam situasi yang timpang ini adalah bahwa perempuan yang berada dalam posisi terpinggirkan dan tidak diuntungkan kemungkinan besar akan kalah. Tidak pernah dipikirkan secara mendasar bahwa kemiskinan dan keadaan terpinggirkan disebabkan karena konstruksi politik dan ekonomi yang disahkan oleh berbagai kebijakan (hukum), yang menjauhkan perempuan dari akses terhadap keadilan dan sumber daya. ${ }^{20}$ Begitu pula dengan keputusan untuk mencari bantuan dan pemilihan penyedia bantuan, penguatan pengetahuan perempuan korban dengan dukungan keluarga, pendamping, dan masyarakat sangat diperlukan. Kesadaran mendapatkan keadilan ini merupakan fondasi dasar keputusan yang diambil bagi perempuan korban untuk mempertimbangkan akses advokasi.

\section{Pemenuhan Advokasi Hak Perempuan dan Anak melalui Model Justice Education dan Clinic Legal Education}

Titik tolak tulisan ini perlu berangkat dari definisi tentang klinis.Klinis adalah (bagian) rumah sakit atau lembaga kesehatan tempat orang berobat dan

${ }^{20}$ Rima Vien Permata Hartanto et.al., "Gerakan Sosial Oleh Paralegal Untuk Peningkatan Akses Keadilan Bagi Perempuan Korban Kekerasan Di Kota Surakarta” Prosiding Seminar Nasional PPKn 2018 "Seminar Nasional Penguatan Nilai-Nilai Kebangsaan Melalui Pendidikan Kewarganegaraan Persekolahan dan Kemasyarakatan” Laboratorium PPKn FKIP UNS, 7 Juli 2018 
memeroleh nasihat medis serta tempat mahasiswa kedokteran melakukan pengamatan terhadap kasus penyakit yang diderita para pasien.Titik tolak hukum klinis mengambil ide dari seorang filosof tekemuka di dunia yang beraliran realisme hukum, yaitu Jerome Frank. Menurutnya, sekolah hukum klinis mengambil inspirasi dari pendekatan dunia nyata yang diambil oleh sekolah kedokteran dalam pendidikan dan pelatihan dokter mereka. ${ }^{21}$

Jerome Frank mendorong untuk pertamakalinya ide tentang klinisisasi hukum dalam kurikulum pengajaran ilmu hukum.Frank mengkritik metode pengajaran studi kasus (case-method) Langdellian, apa yang secara sinis dia sebut sebagai sham case-system, yang menempatkan hukum (kasus hukum) sebagai objek yang hanya bisa dipelajari melalui buku-buku di perpustakaan.

Ide tentang pendidikan klinis hukum sudah muncul sejak 1930-an yang kemudian semakin berkembang setelah pembentukan The Council on Legal Education for Professional Responsibility (CLEPR) oleh The Ford Foundation pada 1967, yang pada tahun-tahun selanjutnya menjadi eksponen penting di balik semakin besarnya minat untuk mengembangkan pendidikan klinis hukum di sekolah-sekolah hukum di Amerika Serikat. ${ }^{22}$ Pengertian klinis hukum merupakan hal yang baru, meskipun gagasan tentang klinis hukum didasarkan pada masa lalu. Menerapkan informasi teoretis yang dipelajari di sekolah hukum ke dalam praktik mungkin memiliki banyak cara berbeda; seperti melakukan magang kejaksaan, pengadilan, notaris, sidang virtual, penyelesaian kasus nyata dan analisis ajudikasi, dan lain-lain. Namun,definisi ini merupakan tempat masyarakat mendapatkan bantuan hukum umumnya dalam bidang hukum internasional.

Klinis ini adalah organisasi nirlaba dan tidak dipungut biaya apa pun. Ketika pertama kali didirikan, klinis hukum merupakan metode bagi mahasiswa hukum untuk mendapatkan pengalaman praktik di beberapa negara.Sekarang, klinis hukum populer di banyak negara, seperti Amerika Serikat, Inggris, Jerman, Prancis, Australia, Italia, Spanyol, dan Portugal. Mereka dapat membuat perbedaan besar bagi komunitas lokal dengan menawarkan layanan pro bono bagi

${ }^{21}$ Miftah Fadli, Pedagogi klinik hukum Kritis. Diversity Of Clinical Legal Education And The Road To Social Justice, FH UI Press, Yogyakarta, 2016

${ }^{22}$ Ibid. 
mereka yang tidak mampu menyewa pengacara. Sedangkan klinishukum merupakan fasilitas yang dijalankan oleh fakultas hukum untuk memberikan pelayanan gratis kepada masyarakat sekaligus melatih mahasiswanya dalam praktik hukum klinis. Mahasiswa hukum bekerja di klinis hukum untuk mendapatkan pengalaman dalam menangani masalah hukum yang nyata.

Tulisan ini memfokuskan pada klinis hukum yang tidak hanya melibatkan fasilitas fisik tersebut, tetapi juga cara-cara yang dapat digunakan dalam praktik.Partisipasi para mahasiswa dalam advokasi perempuan sebaiknya lebih bersifat sukarela dan berdasarkan seleksi, karena tujuan pendidikannya adalah menanamkan konsep pelayanan sosial (public service) dan perlu ada keterlibatan sosial dari profesi hukum. Kedudukan Lab-Hukum tidak kalah penting dalam pendidikan hukum dibandingkan dengan laboratorium-laboratorium fakultas kedokteran.Dalam pendidikan ilmu kesehatan, wadah untuk melakukan pendidikan hukum klinis identik dengan pemberian beragam bantuan hukum bagi masyarakat sekitar. Dalam pendidikan hukum klinis, ada minat yang berkembang dalam pengembangan pekerjaan klinis berbasis berbagai kegiatan, seperti reformasi legislatif dan kebijakan, pengembangan ekonomi masyarakat, dan pendidikan hukum masyarakat. Dalam model kegiatan ini, mahasiswa menggunakan strategi advokasi non-litigasi untuk memecahkan masalah hukum yang menantang bagi klien dan melibatkan berbagai keterampilan hukum multidimensi, termasuk pemecahan masalah yang kompleks, perencanaan strategis, manajemen proyek, dan keterampilan komunikasi profesional.

Fungsi bantuan hukum ini mencakup dua sisi yaitu bantuan hukum secara litigasi dan non-litigasi. Dalam konteks non-litigasi, kegiatan klinis hukum melakukan fungsi sebagai pendamping perempuan korban kekerasan; memberikan pertolongan pertama apabila terjadi pelanggaran hukum. Sedangkan secara litigasi, fungsi klinis hukum mendukung advokat dalam penanganan kasus kekerasan terhadap perempuan. Bantuan hukum yang dapat diberikan dapat berupa konsultasi hukum, advokasi, penyuluhan hukum, pendamping kasus, mediasi, dan pelimpahan kasus.

Pembelajaran berbasis kegiatan menunjukkan bahwa metode pedagogis adalah utama; utamanya memaksimalkan asumsi peran dan kepemilikan mahasiswa atas 
pekerjaan hukum klinis. Karena, model pendidikan hukum klinis memiliki potensi besar untuk menciptakan perubahan pada tataran sistem dan melayani komunitas. Dalam konteks klinis kedokteran, mahasiswa yang mengembangkan asumsi ini sering berjuang untuk mengarahkan keseimbangan antara dampak keadilan sosial dan tujuan pedagogis. ${ }^{23}$ Layanan advokasi saja tampaknya tidak secara dramatis memengaruhi kemampuan perempuan untuk tetap bebas dari kekerasan. Hal ini dikarenakan kerumitan bentuk-bentuk kekerasan yang dialami perempuan yang tidak semua dapat dibuktikan. Misalnya, kekerasan dalam penelantaran rumah tangga. Mengukur indikator penelantaran ekonomi relatif sifatnya. Belum lagi, jika masuk dalam proses persidangan, pelaku malah tidak menghadiri persidangan di pengadilan. Pelecehan seksual menimbulkan perdebatan dalam menentukan identifikasi perbuatan yang dapat dikategorikan sebagai pelecehan apabila dilakukan melalui media sosial secara virtual.Bagi kekerasan fisik, di beberapa tempat termasuk Yogyakarta, disediakan tempat penampungan sebagai pertolongan darurat apabila perempuan merasa terancam. Oleh karenanya, semua komponen ini harus menjadi bagian dari identifikasi yang akurat dan valid serta komprehensif termasuk mengoordinasikan tanggapan masyarakat terhadap para pelaku kekerasan dan korbannya. ${ }^{24}$ Dengan begitu, kita dapat berharap bahwa ini merupakan salah satu cara untuk melihat penurunan yang serius dalam tingkat penganiayaan pria terhadap perempuan.

Pendidikan hukum klinis adalah proses pembelajaran hukum kepada mahasiswa hukum melalui metode pembelajaran dan kurikulum tertentu; metode pengajaran praktis yang memungkinkan mahasiswa untuk secara aktif mengerjakan kasus nyata dan melibatkan mereka dalam aktivitas bantuan hukum. ${ }^{25}$ Tujuan hukum klinis adalah, pertama, memperdalam pengetahuan tentang hukum dan cara hukum bekerja. Kedua, mempraktikkan teori hukum yang dipelajari dengan cara memberikan nasihat hukum secara langsung yang

\footnotetext{
${ }^{23}$ Elliott S. Milstein, "Clinical Legal Education in the United States: In-House Clinics, Externships, andsimulations”, Journal of Legal Education, Vol. 51, No. 3 September 2001, hlm. 375-381

${ }^{24}$ Cris M. Sullivan, 2 Rebecca Campbell, Holly Angelique, Kimberly K. Eby, dan William S. Davidson II, “An Advocacy Intervention Program for Women with Abusive Partners: Six-Month Follow-Up”,American Journal of Community Psychology, VoL 22, No. 1, 1994

25 Alper Uyumaza , Kemal Erdoğan. "The theory of legal clinic in education of law", Procedia - Social and Behavioral Sciences, 174,2015, hlm. 2116 - 2122
} 
biasanya dilakukan pada klien yang kurang mampu. Ketiga, meningkatkan keterampilan untuk belajar mandiri, mengidentifikasi pilihan, membuat keputusan dan mengimplementasikannya, serta keterampilan praktik hukum dan pendidikan moral. Keempat, mengembangkan keterampilan interpersonal dan penyediaan layanan hukum bagi masyarakat kurang mampu. ${ }^{26}$

Pendidikan Hukum Klinis dibedakan dari pendidikan hukum tradisional karena melampaui konten teoretis hukum untuk memberikan kesempatan kepada mahasiswa untuk memperoleh keterampilan yang diperlukandalam praktik hukum. Kelebihannya adalah menanamkan nilai-nilai seperti keterlibatan dalam mengejar keadilan sosial dan tampilan tanggung jawab profesional. ${ }^{27}$

Anthony G. Amsterdam dalam sebuah perkembanganmendeskripsikan teknik dasar yang dapat diterapkan dalam pendidikan hukum klinis. Klinis hukum dikembangkan oleh fakultas hukum dengan membentuk beberapa metode atau model klinis hukum. Model-model tersebut antara lain:

1. Simulasi. Metode yang digunakan dalam model simulasi adalah dengan tidak melibatkan klien yang sesungguhnya, melainkan mahasiswa yang mengembangkan pemahamanan dan keahlian mereka melalui diskusi main peran (role-play);

2. Externship. Ini merupakan model lain dari magang. Di dalam model ini, mahasiswa akan belajar dengan cara melihat, mengimitasi, merefleksi, hingga mempraktikkan secara berulang perilaku hakim atau pengacara;

3. Live-client clinic. Ini dikembangkan dengan melibatkan mahasiswa untuk berhadapan langsung dengan klien. Tujuan dari klinis ini adalah untuk melatih mahasiswa guna mengembangkan tanggungjawab profesional mereka;

4. Street law clinic.Ini ditujukan untuk membangkitkan kesadaran masyarakat mengenai hak dan kewajiban mereka. Kegiatan-kegiatan di dalam street law clinic dapat ditujukan untuk berbagai kalangan masyarakat. ${ }^{28}$

Upaya pemenuhan hak advokasi perempuan melalui pengembangan model clinic legal education dapat ditempuh dengan model live-client clinic dan street law clinic dengan model kurikulum yang tidak hanya berbasis undang-undang saja, namun juga pada rasa keadilan masyarakat. Pemilihan model live-client clinic dan street law clinic untuk kepentingan advokasi wanita korban kekerasan dianggap

\footnotetext{
${ }^{26} \mathrm{Ibid}$.

${ }^{27}$ Rima Vien Permata Hartanto et.al., "Gerakan Sosial...Loc.Cit.

${ }^{28}$ Wanodyo Sulistyani, "Peran Klinik Hukum Dalam Upaya Pemberdayaan Masyarakat (Community Empowerment)"
} 
paling tepat karena selama ini metode pengajaran di fakultas hukum biasanya lebih terfokus pada pengajar/dosen. Kedua metode ini menurut penulis melibatkan lebih banyak keaktifan mahasiswa. Orientasi pada student centered learning membuat mahasiswamemeroleh pengalaman lebih banyak.

Istilahlive-client clinic (klinis klien langsung) telah diadopsi di Australia yang menjelaskan penyampaian pengetahuan, keterampilan, dan sikap praktik hukum secara akademis sebagai bagian dari intelektualisasi pendidikan hukum.29Para mahasiswa berhadapan langsung dengan klien, memetakan masalah, dan memecahkan masalah melalui metode tertentu. Salah satunya, melalui model metode experiential learning. Metode ini relevan digunakan dalam pendidikan hukum klinis yang bersifat non-litigasi. Penelitian dapat dilakukan sebagai pendahuluan untuk memetakan masalah hukum yang nyata; mahasiswa dan dosen melakukan analisis kritis bersama atas masalah tersebut. Pemecahan masalah dapat disampaikan dalam bentuk konsultasi untuk tiap kasus, sosialisasi dengan cara interaktif, pembuatan alat kampanye, pendampingan hukum, hingga penulisan legal opinion. Kasus hukum yang dikerjakan itu nyata, memerlukan tindakan lanjutan. Selanjutnya, perencanaan kegiatan dan pelaksanaannya dikerjakan secara bersama oleh dosen dan mahasiswa, bahkan juga oleh mitra/pihak ketiga yang terlibat dalam kegiatan tersebut. Sesi reflektif tidak ditujukan untuk menilai mahasiswa, tetapi untuk melihat apakah tujuan pembelajaran tercapai. ${ }^{30}$ Dari perspektif pendidikan, klinis hukum melalui model ini harus menerima kerja kasus yang membutuhkan penerapan keterampilan, pengetahuan, dan sikap yang diperlukan untuk pengembangan seorang praktisi hukum profesional. Model ini dapat diterapkan melalui interaksi antara klien, mahasiswa, dan dosen fakultas hukum karena intinya berupa penyediaan layanan langsung. ${ }^{31}$

Clinicstreet law adalah prioritas kurikulum pada keterampilan berpikir kritis mengenai kurikulum yang berfokus pada praktik hukum atau hukum dasar yang

\footnotetext{
${ }^{29}$ John Boersig, James Marshall, Georgia Seaton, "Teaching Law and Legal Practice in a Live Client Clinic",Newc LR, Vo1.6, No.2, 2002

${ }^{30}$ Lidwina Inge Nurtjahyo, "Pendidikan Hukum Klinis Dan Perwujudannya dalam Kurikulum Pendidikan Hukum Di Indonesia”

${ }^{31}$ Ibid
} 
memengaruhi kehidupan sehari-hari. Ini juga menjelaskan praktik berbicara dan bagaimana menjadi pemikir, komunikator, dan pembelajar yang lebih baik. Hukum adalah sarana yang sempurna untuk membantu siswa mengembangkan keterampilan kognitif dan ekspresif sambil juga memperoleh pengetahuan substantif yang praktis dan relevan. Pada tingkat konten, kurikulum ini berfokus pada hukum praktis atau hukum dasar.Untuk membingkai pemahaman ini, kurikulumnya berupaya memberikan pemahaman kepada mahasiswa tentang sistem hukum dan bagaimana proses hukumnya. ${ }^{32}$

Proses pendidikan transformatif tersebut diperluas sasarannya dalam pendidikan hukum klinis, bukan hanya kepada mahasiswa hukum melainkan juga masyarakat umum. ${ }^{33}$ Heuristic menjelaskan bahwa teori yang baik akan menstimulasi penelitian (a good theory generates research). ${ }^{34}$ Perlu ditanamkan, filosofi pendidikan hukum adalah bahwa hukum untuk manusia. Karenanya, hukum harus memahami kondisi yang ada; ini terkait aspek psikologis dan sosiologi dari hukum dalam masyarakat. Pendidikan hukum harus memberikan keteladanan dan pendidikan yang berkarakter, diantaranya, kejujuran. Pendidikan hukum harusjuga menanamkan nilai-nilai bahwa hukum bukanlah untuk golongan tertentu yang memiliki kapital sehingga terasa sangar untuk rakyat kecil. Pendidikan hukum perlu menanamkan nilai-nilai kesetaraan dan egaliter yang mana hukum tidak boleh diskriminitaif dan berpihak karena hal ini akan sulit memenuhi hasrat keadilan.

Hukum memahami keadilan sebagai sebuah tujuan mulia yang merupakan anugerah dan perintah dari Tuhan untuk ditegakkan. Hukum perlu dijalankan dengan penuh pengertian dan rasa keterlibatan yang bahkan memuncak dengan menampilkan kecerdasan spiritual dalam supremasi hukum dan ini tidak hanya berkaitan dengan aturan saja. Hukum juga perlu mempertimbangkan beberapa variabeldi luar hukum seperti sosial, budaya, bahkan politik. ${ }^{35}$

Metode pendidikan klinisdalam konteks advokasi perempuan hendaknya memerhatikannilai-nilai kesetaraan dan egaliter, yang mana hukum tidak boleh

\footnotetext{
${ }^{32}$ Seán G. Arthurs, “Street law: creating tomorrow’s citizens today”, Lewis \& clark law review, 2015

${ }^{33}$ Rosa Tedjabuwana, Hesti Septianita, "Etika Sikap Ilmiah Dalam Pendidikan Hukum Klinis Litigasi", Vol. 20 (2) Oktober, 2019, hlm. 205-22

${ }^{34}$ Ibid.

${ }^{35}$ Ibid.
} 
diskriminitif dan berpihak dengan berbasis keadilan; pengetahuan berkaitan dengan pemahaman teori-teori hukum, asas-asas hukum, dan aturanaturan hukum, dalam arti kombinasi elemen pengetahuan (knowlegde), keahlian (skill), dan nilai-nilai (values).

Desain pendidikan klinis advokasi perempuan dan anak membutuhkan pendukung untuk memajukan kerangka normatif tertentu. Sebagai pekerja sosial klinis yang berubah menjadi pengacara, peran dosen hukum klinis secara profesionalmenjadi penting untuk menyesuaikan kurikulum dalam menerapkan nilai, prinsip, konsep, dan teknik pekerjaan sosial. ${ }^{36}$ Dengan memasukkan unsurunsur inti pekerjaan sosial ke dalam pendidikan hukum klinis, pentingnya pemahaman nilai, prinsip, konsep, dan teknik, membentuk rangkaian terapi melalui pendidikan hukum klinis. Pemahaman initetap dalam koridor bimbingan, pengawasan, dan pendampingan oleh alumni/dosen yang berpengalaman dansesi kelas yang menyeimbangkan pemahaman teori dan praktik klinis yang mendukung dan berkontribusi sebagai pengalaman berharga jika kelak lulus dan menjadi sarjana. Keterlibatan langsung mahasiswa terhadap klien dalam setting praktik yang realistis di sini menjadi menting. Contohnya, metode penggalian informasi klien perempuan dalam konteks yang didasarkan titik tolak netral, objektif, dan ilmiah.

Pertanyaan pada kasus pelecehan seksual kepada klien dapat dimulai dari pertanyaan tentang tujuan dalam menggali kasus ini. Misalnya dapat dideskripsikan melalui pertanyaan: Bagaimana mendefinisikan perbuatannya ke dalam bahasa hukum? Mungkinkah mendefinisikan makna pelecehan seksual secara berbeda? Apa argumen dalam mendefinisikan tindak pidananya? Apa cara yang tersedia untuk mencapai tujuan advokasi pada klien? Cara berpikir apa yang akan memperluas pilihan penyelesaiannya? Apa harapan klien dan bagaimana reaksi mereka terhadap penyelesaian yang ditawarkan?

Praktik ini tentu saja didasari pada penguasaan norma, asas, dan teori hukum yang telah dipelajari secara komprehensif sebelumnya. Perpaduan antara teori dan praktik dalam menggali data dapat menghasilkan kombinasi yang

${ }^{36}$ Susan L. Brooks, "Practicing (And Teaching) Therapeutic Jurisprudence: Importing Social Work Principles And Techniques Into Clinical Legal Education”,ST Thomas Law Review, 2005 
akurat dan valid. Egalitarian relationshipmenjadi penting dalam praktik pendidikan hukumyang merupakan bentuk hubungan antara konselor dengan konseli. Kiselicadan Robinson (2001) menjelaskan bahwa peran konselor dalam menjalankan advokasi sosial dilatarbelakangi oleh dua faktor, yaitu: a) konselor bekerja dalam dalam konteks sosial di tempat permasalahan terjadi dan b) kerja konselor terkait erat dengan dengan upaya profesional untuk membantu pihak yang menempuh koseling keluar dari situasi tidak adil dan tidak setara dalam masalah yang dihadapi. ${ }^{37}$

Konseling dipandang sebagai proses kerjasama yang setiap individu dihargai dalam kapasitas kekuatan yang sama untuk mendiskusikan pokok masalah dan strategi pemecahan masalahnya. Ditambahkan lagi bahwa walaupun metode kerjasama ini tidak mungkin untuk dilakukan pada setiap konseling, tetapi proses ini harus tetap dilaksanakan sebagai salah satu tahap dalam konseling feminis. Egalitarian relationship menggunakan pendekatan dasar humanistik yaitu mendengar secara empatik, dorongan tak bersyarat (unconditional support), mutual respect, membantu membuka ketertutupan konseli secara tepat. 38

\section{Penutup}

Terdapat setidaknya enam kelompok perempuan dalam memahami pengetahuan akses advokasi yaitu, pertama, kelompok perempuan yang sama sekali tidak tahu haknya untuk mendapatkan perlindungan. Kedua, kelompok perempuan mengetahui hak-haknya tetapi tidak tahu kemana harus pergi untuk mengakses keadilan. Ketiga, kelompok perempuan yang tahu harus pergi kemana dan hak mengakses keadilan tetapi tidak memiliki sarana atau kemampuan finansial untuk mengakses keadilan. Keempat, kelompok perempuan yang learned helpness dan apatis dengan kondisi lalu menerima kenyataan sebagai korban. Kelima, kelompok perempuan yang takut pelakunya akan membalas dendam jika mereka mencari bantuan hukum. Keenam, kelompok perempuan yang memiliki kesadaran tinggi dan berupaya mencari solusi atas kekerasan yang dialaminya.

\footnotetext{
37 Sigit Sanyata, "Paradigma Konseling Berperspektif Gender Pada Kasus Kekerasan Dalam Rumah Tangga”, Jurnal Bimbingan Konseling, 2017

${ }^{38}$ Ibid.
} 
Upaya pemenuhan hak advokasi perempuan melalui pengembangan model clinic legal education dapat ditempuh dengan model live-client clinic dan street law clinic dengan model kurikulum yang tidak hanya berbasis pada undang-undang saja, namun juga pada rasa keadilan masyarakat.

Adapun dari uraian di atas saran Penulis, pertama, pendidikan hukum klinis bagi perempuan harus mampu mengantarkan mahasiswa mengembangkan kemampuannya memahami secara kritis memandang hukum bukan sebagai realitas yang statis, tetapi sebagai realitas yang berada dalam proses,dalam gerak perubahan. Kedua, pentingnya pemahaman nilai, prinsip, konsep, dan teknik membentuk rangkaian terapi melalui pendidikan hukum klinis. Pentingnya prinsip pemahaman values, principles, concepts, and techniques yang terukur ilmiah dan objektif. Ketiga, perlunya hubungan egalitarian yang mengedepankan dan menjunjung tinggi menjunjung nilai-nilai Ilahiyah: kejujuran, anti-diskriminasi, dan terutama mengusung keadilan sosial.

\section{Daftar Pustaka}

\section{Buku}

Fadli, Miftah, Pedagogi Klinik Hukum Kritis. Diversity of Clinical Legal Education And The Road To Social Justice, FH UI Press, Yogyakarta, 2016.

\section{Jurnal}

Arthurs, Seán G., "Street law: creating tomorrow's citizens today", Lewis EClark Law Review, 2015

Boersig, John, James Marshall, Georgia Seaton, "Teaching Law and Legal Practice in a Live Client Clinic", Newc LR, Vo1.6, No.2, 2002.

Brooks, Susan L., "Practicing (And Teaching) Therapeutic Jurisprudence: Importing Social Work Principles And Techniques Into Clinical Legal Education", ST Thomas Law Review, 2005.

Goodman, Lisa, Pratyusha Tummala-Narra, dan Sarah Weintraub, "A Theoretical Framework for Understanding Help-Seeking Processes Among Survivors of Intimate Partner Violence Belle Liang", American Journal of Community Psychology, Vol. 36, No. 1/2, September 2005.

Milstein, Elliott S., "Clinical Legal Education in the United States: In-House Clinics, Externships, andsimulations", Journal of Legal Education, Vol. 51, No. 3, September 2001.

Sanyata, Sigit, "Paradigma Konseling Berperspektif Gender Pada Kasus Kekerasan Dalam Rumah Tangga", Jurnal Bimbingan Konseling, 2017 
Siregar, Sahnan Sahuri, Otong Rosadi, "Pendidikan Klinik Hukum Sebagai Instrumen Penting Dalam Pembaharuan Pendidikan Hukum Di Indonesia", Journal Swara Justicia, Volume 3, Issue 4, Januari 2020.

Sullivan, Cris M., 2 Rebecca Campbell, Holly Angelique, Kimberly K. Eby, dan William S. Davidson II, "An Advocacy Intervention Program for Women with Abusive Partners: Six-Month Follow-Up", American Journal of Community Psychology, VoL 22, No. 1, 1994.

Sullivan, Cris M., Cheribeth Tan, Joanna Basta, Maureen Rumptz, and William S. Davidson II, "An Advocacy Intervention Program for Women with Abusive Partners: Initial Evaluation I", American Journal of Community Psychology, Vol. 20, No. 3, 1992.

Tedjabuwana, Rosa, Hesti Septianita, "Etika Sikap Ilmiah Dalam Pendidikan Hukum Klinis Litigasi", Vol. 20 (2) Oktober, 2019.

Uyumaza, Alper, Kemal Erdoğan. "The theory of legal clinic in education of law”, Procedia - Social and Behavioral Sciences, 174, 2015.

Weisz, Arlene N., "Legal advocacy for domestic violence survivors: The power of an informative relationship Families in society", The Journal of Contemporary Human Services, 1999.

Yustia, Rd.Dewi Asri et.al, "Mendobrak kelemahan litigasi konvensional melalui model advokasi mandiri dalam rangka pembaharuan proses peradilan", Jurnal Litigasi, 2015.

Artikel

Sulistyani, Wanodyo, "Peran Klinik Hukum Dalam Upaya Pemberdayaan Masyarakat (Community Empowerment)"

Nurtjahyo, Lidwina Inge, "Pendidikan Hukum Klinis Dan Perwujudannya dalam Kurikulum Pendidikan Hukum Di Indonesia"

Muttaqin, M. Asasul, et.al., "Bimbingan Konseling bagi Perempuan Korban KDRT"

Hartanto,Rima Vien Permata, et.al., “Gerakan Sosial Oleh Paralegal Untuk Peningkatan Akses Keadilan Bagi Perempuan Korban Kekerasan Di Kota Surakarta" Prosiding Seminar Nasional PPKn 2018 "Seminar Nasional Penguatan Nilai-Nilai Kebangsaan Melalui Pendidikan Kewarganegaraan Persekolahan dan Kemasyarakatan" Laboratorium PPKn FKIP UNS, 7 Juli 2018

Omoragbon, Kevwe, "Interface of Law and Medicine in Clinical Legal Education: Success story of the Women's Law Clinic in improving the health of women and ensuring women's access to Justice in Nigeria" Paper presented at the Seventh International Journal of Clinical Legal Education held at Murdoch University, Perth, Western Australia, July 9-10, 2009 


\section{Internet}

https:/ / www.komnasperempuan.go.id/read-news-siaran-pers-dan-lembar-faktakomnas-perempuan-catatan-tahunan-kekerasan-terhadap-perempuan-2020 http:/ / www.harnas.co/2019/04/04/penuntasan-kdrt-secara-hukum-minim https:/ / nasional.kontan.co.id/news/selama-pandemi-corona-kekerasan-terhadapperempuan-naik-75

https:/ / magdalene.co/story/hotline-pengaduan-kdrt-banyak-laporan-sumberdaya-terbatas 